\section{References}

Blackman, J. E., Gibson, G. R., Lavan, J. N., Learoyd, H. M., and Posen, S. (1967). British Medical foumal, 2, 800 .

British Medical fournal, 1971, 2, 61 .

Claireaux A E (1953). Fournal of Pathology and Bacteriology, 65, 291

Cohen, M. E. L., Cohen, G. F., Ahad, V., and Kaye, M. (1970). Clinical Radiology, 21, 124.

Follis, R. H., and Jackson, D. A. (1943). Bulletin of the fohns Hopkins Hospital, 72, 232.

Follis, R. H., Jackson, D., Eliot, M. M., and Park, E. A. (1943). American Fournal of Diseases of Children, 66, 1 .

Garner, A., and Ball, J. (1966). Fournal of Pathology and Bacteriology, 91, 545. Garrick, R., Doman, $\dot{\mathbf{P}}_{\text {., }}$ and Posen, S. (1972). Clinical Science, 53, 789.

Garrick, R., Ireland, A. W., and Posen, S. (1971). Annals of Internal Medicine, 75, 221.

Hall, M. C., Elmore, S. E., Bright, R. W., Pierce, J. G., and Hume, D. (1969). Fournal of the American Medical Association, 208, 1825.

Harrington, K. D., Murray, W. R., Kountz, S. L., and Belzer, F. O. (1971). fournal of Bone and foint Surgery, 53A, 203.

Haust, M. D., Landing, B. H., Holmstrand, K., Currarino, G., and Smith, B. S. (1964). American fournal of Pathology, 44, 141.

Heptinstall, R. H. (1968). American fournal of Medicine, 44, 656

Hocking, D. R. (1964). Medical fourmal of Australia, 2,915.

Jennis, F., Lavan, J. N., Neale, F. C., and Posen, S. (1970). British fournal of Urology, 42, 511 .

Johnson, J. W., et al. (1971). Fournal of the American Medical Association, 215, 478.
Jowsey, J., Johnson, W. J., Taves, D. R., and Kelly, P. J. (1972). Fournal of Laboratory and Clinical Medicine, 79, 204.

Katz, A. I., Hampers, C. L., and Merrill, J. P. (1969). Medicine, 48, 333.

Kaye, M., Chatterice, G., and Cohen, G. F. (1969). Proceedings of the Fourth International Congress of Nephrology, Stockholm, 3, 151.

Kleeman, C. R., Massry, C. G., Coburn, J. W., and Popovtzer, M. M. (1969). Archives of Internal Medicine, 124, 262.

Lavan, J. N., Benson, W., Gatenby, A. H., and Posen, S. (1966). Medical fournal of Australia, 2, 694.

Lucas, R. C. (1883). Lancet, 1, 993.

Lumb, G. A., Mawer, E. B., and Stanbury, S. W. (1971). American fournal

O'Riordan, J. L. H., et al. (1970). Quarterly fournal of Medicine, 39, 359.

Parfitt, A. M. (1972). Orthopedic Clinics of North America, 3, 681.

Perkoff, G. T. (1967). New England Yournal of Medicine, 277, 129.

Posen, S., Neale, F. C., and Clubb, J. S. (1965). Annals of Internal Medicine,

62, 1234. Australia, 1, 421

Australia, 1, 421.
Shapiro, R. (1971). American fournal of Roentgenology, 111, 750.

Siegelman, S. S. (1970). In Osteoporosis, ed. U. S. Barzel, p. 68. New York, Grune and Stratton.

Stanbury, S. W. (1957). British Medical Bulletin, 13, 57.

Stanbury, S. W. (1968). American fournal of Medicine, 44, 714.

Steinbach, H. L., et al. (1961). American fournal of Roentgenology, 86, 329.

Steinbach, H. L., and Noetzli, M. (1964). American fournal of Roentgenology, 9, 955 .

\title{
Diagnosis of Gonorrhoea in Women: Comparison of Sampling Sites
}

\author{
M. N. BHATTACHARYYA, A. E. JEPHCOTT, R. S. MORTON
}

British Medical fournal, 1973, 2, 748-750

\section{Summary}

A total of 250 women, 100 of them named contacts of men with gonorrhoea, were tested for infection. Each had prepared smear and culture specimens from urethra, endocervix, and vagina. The smears were Gram-stained and examined immediately. Cultures were taken using Stuart's transport medium with later inoculation of both selective and non-selective media for each specimen.

It was shown that examination of specimens from urethra and endocervix gave results superior to those found on examination of vaginal material alone. The study revealed that nearly one infected woman in three would have been missed if vaginal material only had been examined. Failure to secure a prompt scientific diagnosis has serious epidemiological implications.

Our results find support in the work of others. We conclude that the suggestion in some quarters that examination of vaginal material for the detection of gonococci is adequate should be abandoned. Any who feel unwilling to accept this view should at least supplement their testing with examination of urethral and endocervical specimens.

\section{Introduction}

Conflicting advice is offered by British gynaecological textbooks concerning the most appropriate sampling methods for the bacteriological diagnosis of gonorrhoea in women.

Royal Infirmary, Sheffield S6 3DA

M. N. BHATTACHARYYA, M.B., M.R.C.o.G., Senior Registrar, Department of Venereology

R. S. MORTON, F.R.C.P., Consultant Venereologist,

Public Health Laboratory, Sheffield S5 7AU

A. E. JEPHCOTT, M.B. M.R.C.PATH., Consultant Microbiologist
Stern (1963) said: "a swab should be taken high in the vagina and cultured." Willcox (1963), however, advised that urethral and cervical specimens be taken for microscopy and culture. Jeffcoate (1967), discussing acute salpingo-oophoritis, said: "cervical (or high vaginal) and urethral swabs" should be taken; though later, when commenting on the asymptomatic nature of early gonorrhoea, he advised preparation of urethral and endocervical smears and cultures. Peel and Brudenell (1969) advised the examination of cervical smears and cultures for the diagnosis of gonorrhoea but did not mention urethral sampling. Howkins and Bourne (1971) suggested urethral with either high vaginal or cervical swabbing, though Nicol (1971) specified the urethral and cervical sites only. Baird (1969) mentioned smears and cultures but did not specify sites to be tested.

Textbooks for nurses show the same dichotomy. Catterall (1964) advised urethral and cervical examinations, while in contrast textbooks offered to student nurses in midwifery (Hallam, 1972) and gynaecology (Dodds, 1967) support the taking of vaginal swabs.

It is to be expected that the confusion of opinion expressed in these textbooks will be reflected in clinical practice. Moreover, the situation has now become further complicated by the availability of new laboratory techniques with more sophisticated ways of overcoming contamination, which could possibly make the vaginal specimen more acceptable.

To resolve these uncertainties and to establish how useful in fact the vaginal specimen can be in present circumstances, a trial was carried out comparing it with more appropriate urethral and cervical specimens.

\section{Material and Methods}

The study covered 250 women who attended the special clinic, Royal Infirmary, Sheffield, between February and August 1972.

Group 1 consisted of 150 patients, of whom 50 were named sex partners of men with gonorrhoea. Group 2 consisted of 100 patients, 50 of whom were named contacts of gonorrhoea. The patients were in no way selected, and represent in terms of age and marital status the population of the clinic. 
All patients-both contacts and other new patients-were interviewed and clinically examined at their first attendance. The following investigations were then carried out: in group 1 urethral, vaginal vault, and endocervical specimens were taken. The vaginal specimens were taken from the vault under direct vision using a Cusco speculum, with the patient in the lithotomy position; in group 2 the procedure was identical apart from the method of taking the vaginal specimens. In view of the difficulty in obtaining satisfactory vaginal vault specimens from a patient lying in a hospital bed and without the use of a speculum, samples were taken blindly from the lower vagina.

Smears were made of specimens from both groups, stained by Gram's method, and immediately examined in the clinic. Cultures were similarly taken using carbon impregnated swabs and were sent to the laboratory in Stuart's transport medium. They were usually "plated out" within 24 hours. Two culture media were used for each specimen, Columbia chocolate agar (Ellner et al., 1966) and trimethoprim-containing medium but without nystatin (Phillips et al., 1972). Plates were incubated in 10\% carbon dioxide for 36-48 hours. Positive cultures were identified by Gram stain, oxidase reaction, and appropriate carbohydrate acidification on Flynn and Waitkin's (1972) medium.

\section{Results}

In Group 1, 29 contacts were diagnosed by examination of smear and culture specimens from urethra, endocervix, or vaginal vault (see table). In one instance only was the vaginal specimen positive when the urethral and endocervical ones were negative. On no fewer than eight occasions the reverse held true. The difference is significant at the $2 \%$ level. Of the other 100 patients in group 1, 10 were found infected by examination of vaginal smears and cultures but two more were found only by urethral and endocervical smear or culture examination. This difference is not statistically significant.

Diagnosis of Gonorrhoea by Urethral and Endocervical Smear and Culture and by Vaginal Smear and Culture. (Results Concern Patients' First Attendance only)

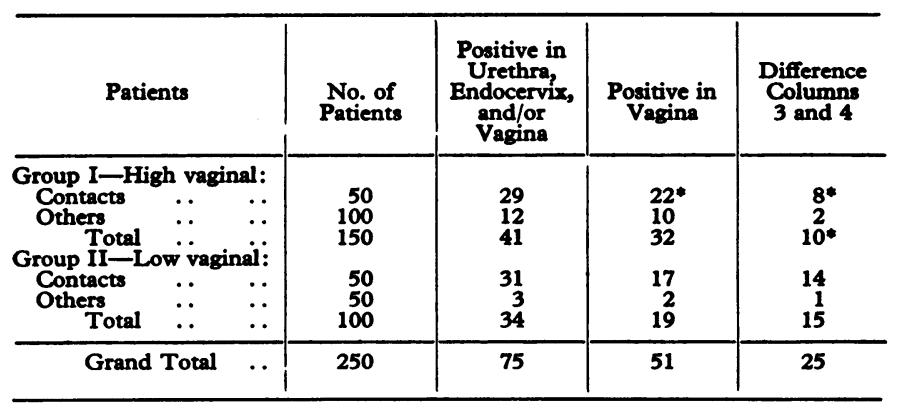

- In one patient only the vaginal culture was positive.

In the 50 named contacts in group 2 a total of 31 positive results were obtained by all methods used. Of these only 17 yielded positive vaginal smears or cultures. This difference is highly significant $(P<0.001)$. The diagnostic abilities of the methods in group 2 "other patients" are not significantly different, but the results obtained by examination of "low vaginal" specimens were significantly inferior to those obtained with the "high vaginal" specimens $(P<0.01)$.

In terms of the grand total the diagnostic shortfall using vaginal material was nearly one in every three patients.

\section{Discussion}

Recent series like ours have all shown a significant shortfall in the diagnostic ability of the vaginal swab. Thus Olsen (1971), who examined cultures and analysed his material on the supposition that he had found $100 \%$ of positive infections, showed that $96.2 \%$ were detected by urethral or cervical tests or both, whereas only $79.2 \%$ were found by examination of vaginal specimens. Similarly, Schmale et al. (1969) testing four sitesurethra, cervix, vagina, and rectum-found $93.8 \%$ of total positive diagnoses on urethral or cervical culture or both as against $\mathbf{7 7 \cdot 7} \%$ from the vaginal cultures.

These results are not unexpected. The prime reason for the inadequacy of the vaginal specimen must lie in the pathology of the disease. Thus, cervical and urethral samplings are taken from the sites of infection where gonococci are actively multiplying, whereas the vaginal specimen merely detects any bacteria which may have contaminated a neighbouring area.

Two possible secondary reasons suggest themselves; either the selective media used do not inhibit contaminants or gonococci do not survive long in the vagina.

Like others, Wilkinson (1965) showed that selective media are in fact of undoubted value in preventing overgrowth of gonococci by other organisms-especially from sites such as the vagina where the presence of a dense bacterial flora is inevitable. In our series the selective medium allowed $26.1 \%$ more isolations to be made from this site than would have been possible had the non-selective medium been used alone. Thus, despite this increased testing sensitivity, in our trial the vaginal specimen still compared unfavourably.

The second contention-that delicate gonococci do not survive long in the vagina seems a much more likely explanation. In like manner, our results show that specimens taken from lower in the vagina are less likely to yield positive results than those from the vault, again suggesting a fairly short life for those gonococci in the vagina.

Gonorrhoea is now a world-wide epidemiological problem. With the advent of sexual freedom and the growing use of oral contraception, particularly in western countries, the prevalence of the disease in women is growing much faster than in men (Watt, 1964; Morton, 1970). Salpingitis is more common than all the other complications of gonorrhoea taken together and is now said to occur in no less than $10 \%$ of infected females (Rees, 1964; Rees and Annels, 1969).

The prompt and accurate bacteriological diagnosis of occult and complicated gonorrhoea in women has thus become a more urgent problem than ever before. Moreover, the highest possible yield of positive results is not only of some importance to the individual patient, it has epidemiological implications. Without a scientifically sound diagnosis of gonorrhoea, the tracing and treating of sex contacts becomes inefficient and so public health control of the infection cannot be initiated, pursued, or maintained. In the present epidemic state of gonorrhoea this aspect is of vital importance if the disease is to be kept within manageable proportions. To this end we feel it is essential that specimens are taken which maximize the possibility of arriving at diagnosis of gonococcal infection.

Our thanks are due to our staffs for technical help. In particular, we thank Mr. W. E. Shaw, and Mr. B. N. Collins. We are also in debt to Miss Mary Hogan of the statistics section of the Sheffield Regional Hospital Board.

\section{References}

Baird, Sir D. (1969). Combined Textbook of Obstetrics and Gynaecology for Students and Practitioners, 8th edn., p. 739. Edinburgh, Livingstone. Catterall, R. D. (1964). Venereology for Nurses, 1st edn., p. 6. London, English Universities Press.

Dodds, Gladys H. (1967). Gynaecology. A Handbook for Nurses, 5th edn., p. 122. London, Faber \& Faber.

Ellner, P. D., Stoessel, Carole J., Drakeford, Elaine, and Vasi, F. (1966). American fournal of Clinical Pathology, 45, 502.

Flynn, J., and Waitkins, Sheena (1972). Fournal of Clinical Pathology, 25, 525. Hallam, Jean L. (1972). Midwifery for Nurses, 1st edn., p. 87. London, English Universities Press.

Howkins, J., and Bourne, G. L. (1971). Shaw's Textbook of Gynaecology, 9th edn., p. 783. Edinburgh, Churchill Livingstone. 
Jeffcoate, Sir T. N. A. (1967). Principles of Gynaecology, 3rd edn., pp. 368, 369 , and 418. London, Butterworth.

Morton, R. S. (1970). British Fournal of Venereal Diseases, 46, 103.

Nicol, C. S. (1971). Shaw's Textbook of Gynaecology, revised by J. Howkins and G. L. Bourne, 9th edn. p. 239. Edinburgh, Churchill Livingstone.

Olsen, G. A. (1971). British fournal of Venereal Diseases, 47, 102.

Peel, Sir J. H., and Brudenell, J. M. (1969). Textbook of Gynaecology, 6th edn., p. 181. London, Heinemann.

Phillips, I., Humphrey, D., Middleton, A., and Nicol, C. S. (1972). British Fournal of Venereal Diseases, 48, 287.

Rees, E. (1964). Bulletin of the Institute of Technicians in Venereology, 6, 87
Rees, E., and Annels, E. H. (1969). British Fournal of Venereal Diseases, 45, 205

Schmale, J. D., Martin, J. E., and Domescik, G. (1969). Fournal of the American Medical Association, 210, 312

Stern, D. M. (1963). In British Obstetrics and Gynaecological Practice, ed. A. Bourne and Sir A. Claye, 3rd edn., Gyna ecology vol., p. 534. London, Heinemann

Watt, L. (1964). British Medical fournal, 2, 858

Wilkinson, A. E. (1965). British fournal of Venereal Diseases, 41, 60.

Willcox, R. R. (1963). In British Obstetrics and Gynaecological Practice, ed A. Bourne and Sir A. Claye, 3rd edn., Gynaecology vol., p. 826. London, Heinemann.

\title{
Oestrogen Receptor in Human Breast Cancer Tissue and Response to Endocrine Therapy
}

\author{
E. ENGELSMAN, J. P. PERSIJN, C. B. KORSTEN, F. J. CLETON
}

British Medical fournal, 1973, 2, 750-752

\begin{abstract}
Summary
Oestrogen receptor determinations were done in metastatic breast cancer tissue of patients with advanced breast cancer. In 37 patients with progressive disease evaluation of the response to endocrine treatment was possible, following the criteria of the E.O.R.T.C. Cooperative Breast Cancer Group. In 20 patients with receptor-negative tumours two objective remissions were noted; in 17 patients with receptor-positive tumours 14 objective remissions were seen. There seems to be a striking correlation between the presence or absence of oestrogen receptor in tumour tissue and the clinical response to hormonal therapy.
\end{abstract}

\section{Introduction}

A correlation between the presence of a specific oestrogen receptor in breast cancer tissue and the response to endocrine treatment has been shown in rats (King et al., 1965; King et al., 1966; Jensen et al., 1967; Trams and Maass, 1969). Evidence for a similar correlation in human breast cancer was reported by Jensen et al. (1972) and Maass et al. (1972). An increased in-vivo uptake of injected radiolabelled oestrogens by human breast cancers was also shown in patients who subsequently responded to endocrine therapy (Folca et al., 1961; Braunsberg et al., 1973).

In our institute oestrogen receptor determinations have been carried out since 1971 in primary breast cancers and in biopsy specimens taken from skin and lymph node metastases. In 37 patients with progressive advanced breast cancer the clinical response to endocrine treatment has now been evaluated and compared with the results of receptor determinations in metastases sampled for biopsy shortly before the start of therapy. In 20 of these patients the treatment and follow-up were part of a clinical trial of the E.O.R.T.C. Breast Cancer Group.

Department of Internal Medicine, Netherlands Cancer Institute, Antoni van Leeuwenhoekhuis, Amsterdam

E. ENGELSMAN, M.D., Internist

F. J. CLETON, M.D., Internist

Department of Clinical Chemistry, Netherlands Cancer Institute, Antoni van Leeuwenhoelhuis, Amsterdam

J. P. PERSIJN, PH.D., Clinical Chemist
C. B. KORSTEN, PH.D., Clinical Chemist

\section{Patients and Methods}

The oestrogen receptor determinations were done in tissue homogenates by a charcoal separation technique (Korsten and Persijn 1972). All tissue specimens were taken from skin and lymph node metastases. In all tissue samples the presence of tumour was verified histologically. Therapy was started after the specimen had been taken but before the receptor content was known. All the patients had evidence of progressive disease and had lesions which could be evaluated objectively (skin and lymph node metastases, lung metastases, well-defined osteolytic bone metastases). The patients were investigated and followed up according to the criteria outlined in the E.O.R.T.C. Co-operative Breast Cancer Group protocol (G.E.C.A., 1967).

An objective remission was accepted when measurable regression was noted in at least half of the lesions, without progression in any lesion and without any new lesion arising anywhere. The improvement had to last for more than three months. In four patients who responded well to treatment and who had no evidence of bone metastases no follow-up skeletal $x$-ray films were obtained.

Endocrine therapy was thought to be indicated only when the disease was too widespread to be controlled by palliative radiotherapy or when progression was noted in irradiated areas. Nine premenopausal women underwent oophorectomy; the other 28 patients were two or more years postmenopausal and were treated with either ethinyloestradiol (Lynoral) $3 \mathrm{mg}$ daily or nandrolone phenylpropionate (Durabolin) $25 \mathrm{mg}$ three times a week or nafoxidine (U 11100) $180 \mathrm{mg}$ daily. Nafoxidine is an oestrogen antagonist which was shown to produce remission in about $30 \%$ of cases of advanced breast cancer in type 1 and type 2 clinical trials carried out by the E.O.R.T.C. Breast Cancer Group (1972, 1973). In 35 patients this was the first endocrine treatment given. Two patients had had endocrine therapy (oophorectomy, ethinyloestradiol) previously but the biopsy specimens were taken when there was a recurrence of the progressive disease and the preceding therapy had been stopped for more than six weeks.

\section{Results}

Out of 17 patients found to have receptor in their tumour tissue 14 experienced an objective remission (table I). Of the 20 patients in whom the tumour tissue was receptor-negative only two had an objective remission (table II). Application of the $\mathrm{X}^{2}$ test gave $\mathrm{P}<0.00001$. There seemed to be no relation between the quantity of receptor measured and the quality and duration of the remission obtained. The amounts of receptor 